International Journal of Current Microbiology and Applied Sciences

ISSN: 2319-7706 Volume 6 Number 2 (2017) pp. 1735-1741

Journal homepage: http://www.ijcmas.com

Original Research Article

http://dx.doi.org/10.20546/ijcmas.2017.602.194

\title{
Effect of Potassium Humate and Bio-inoculants on Nutrient Content, Uptake and Quality of Cowpea (Vigna unguiculata (L.) Walp)
}

\author{
Pradip Tripura $^{1}$, Sunil Kumar ${ }^{2 *}$ and Rajhans Verma ${ }^{3}$ \\ ${ }^{1}$ Department of Soil Science and Agricultural Chemistry JAU, Junagharh, India \\ ${ }^{2}$ Department of Agronomy, IAS, BHU, Varanasi-221 005, India \\ ${ }^{3}$ Department of Soil Science and Agricultural Chemistry, SKNAU, Jobner-303 329, India \\ *Corresponding author
}

\begin{tabular}{|c|c|}
\hline & A B S T R A C T \\
\hline $\begin{array}{l}\text { Ke e y w o r d s } \\
\text { Potassium } \\
\text { humate, Bio- } \\
\text { Inoculants, }\end{array}$ & \multirow{3}{*}{$\begin{array}{l}\text { A pot experiment was conducted during kharif season of } 2014-15 \text { at the } \\
\text { cage house, Sri Karan Narendra Agriculture University, Jobner. The } \\
\text { application of potassium humate and seed inoculation with bio-inoculants } \\
\text { significantly increased the NPK content and uptake, quality and yield of } \\
\text { cowpea. The results revealed that the higher values of NPK content, uptake } \\
\text { and Protein content in seed of cowpea are obtain under the application of } \\
\text { potassium humate @ } 10 \mathrm{mg} / \mathrm{kg} \text { soil and Rhizobium + VAM + PSB seed } \\
\text { inoculation than other treatment. }\end{array}$} \\
\hline Article Info & \\
\hline $\begin{array}{l}\text { Accepted: } \\
\text { 24 January } 2017 \\
\text { Available Online: } \\
\text { 10 February } 2017\end{array}$ & \\
\hline
\end{tabular}

\section{Introduction}

Cowpea (Vigna unguiculata (L.) Walp) commonly known in India as lobia is one of the important kharif pulse crops grown for vegetable, grain, forage and green manuring. Cowpea grains contain $25 \%$ protein, and several vitamins and minerals. It is known as vegetable meat.

Green tender pods are used as vegetable, the vegetable cowpea pods contain moisture $84.6 \%$, protein $4.3 \%$, carbohydrate $8.0 \%$ and fat $0.2 \%$ it is also rich a source of calcium, phosphorus and iron. In India, cowpea was grown over an area of $25.43 \mathrm{~m}$ ha with production of $19.27 \mathrm{~m} \mathrm{t}$ (GOI, 2013). In Rajasthan, cowpea covers an area of 0.61 lakh ha with a production of 0.33 lakh tonnes (GOR, 2013).

Humic substances are natural organic poly electrolytes present in the soil humus and stabilized soil organic matter. Humic acid enhances plant growth, nutrient uptake and improves stress tolerance in plants (Serenella et al., 2002). Potassium humate is a good source of humic acid. Its stimulation to plant growth is a function of nutrients supply to the plant. A clear significantly positive trend was seen in increasing plant height, stem diameter and root length by increasing the concentration of potassium humate (Sahar et al., 2009). 
The important characteristic of biofertilizer association with crop improvement is secretion of ammonia in the rhizosphere in the presence of root exudates, which helps in modification of nutrient uptake by the plants (Narula and Gupta, 1986). The ability of Azospirillum to produce plant growth regulatory substances along with $\mathrm{N} 2$ fixation stimulate plant growth and thereby productivity. The changes that occur in the plant roots help in transport of minerals and water (Sarig et al., 1988). In order to reduce the use of chemical fertilizers, biofertilizer could play a crucial role by fixing the atmospheric nitrogen for the crops and/or by increasing the availability of phosphorus and other nutrients to the crops (Selva kumar et al., 2012).

\section{Materials and Methods}

A pot experiment was conducted during kharif season of 2014 at the Cage house, Sri Karan Narendra Agriculture University, Jobner. Total fifteen treatments were assigned in complementary block design with three replications. Three level of potassium humate (control, $5 \mathrm{mg} / \mathrm{kg}, 10 \mathrm{mg} / \mathrm{kg}$ ) are apply at the time of sowing and seed inoculate with five level of bio-inoculants viz. control, Rhizobium + VAM, Rhizobium + PSB, VAM + PSB, and Rhizobium + VAM + PSB. The cowpea var. 'RC-19'were sown at pot and maintain 5 plant in each pot. The cowpea were sown on 25 July 2014 and finally harvested on 28 September 2014. Resultsregards to nutrient content and uptake and protein content were noted after harvest. The protein was estimated in the cowpea seed by the method of Lowry et al., (1951).

The collected samples were dried and thereafter ground to a fine powder for estimation of NPK content (\%) of the leaf and head. Nitrogen content in the head and plant was estimated by using Nesselar's reagent by spectrophotometer method (Snell and Snell, 1949). Phosphorus was estimated by spectrophotometer method using tri acid ammonium molybdante ammonium wabnadete solution (Jackson, 1973). Potassium content was estimated by using flame photometer (Richards, 1954).

The uptake of nitrogen, phosphorus and potassium at harvest in grain and straw was estimated by using the following formula.

Seed and straw

yield $(\mathrm{g} / \mathrm{pot})$

Uptake (mg/pot) = ----------------------------------------- X 100

\section{Results and Discussion}

A perusal of data presented in Table-1 revealed that with the application of potassium humate, there was a significant increase in $\mathrm{N}, \mathrm{P}$ and $\mathrm{K}$ content and uptake in seed and straw of cowpea under $\mathrm{KH}_{1}$ and $\mathrm{KH}_{2}$ treatments as compared to control $\left(\mathrm{KH}_{0}\right)$. However, the increase in $\mathrm{N}, \mathrm{P}$ and $\mathrm{K}$ content and uptake in grain and straw with $\mathrm{KH}_{2}$ treatment was statistically at par with $\mathrm{KH}_{1}$ treatment.

In the present study the application of potassium humate increased the $\mathrm{N}, \mathrm{P}$ and $\mathrm{K}$ content, uptake and protein. Potassium humate contains humic acid and fulvic acid. Humic acid consist of nitrogen, potassium, phosphorus and other important plant growth promoting micro nutrients minerals. 
Table.1 Effect of potassium humate and bio-inoculants on N, P and K content and uptake in seed and straw of cowpea

\begin{tabular}{|c|c|c|c|c|c|c|c|c|c|c|c|c|}
\hline \multirow[t]{3}{*}{ Treatments } & \multicolumn{4}{|c|}{$\begin{array}{c}\text { Nitrogen } \\
\end{array}$} & \multicolumn{4}{|c|}{ Phosphorus } & \multicolumn{4}{|c|}{$\begin{array}{c}\text { Potassium } \\
\end{array}$} \\
\hline & \multicolumn{2}{|c|}{$\mathrm{N}$ content $(\%)$} & \multicolumn{2}{|c|}{ N uptake(g/pot) } & \multicolumn{2}{|c|}{$P$ content $(\%)$} & \multicolumn{2}{|c|}{$\begin{array}{c}P \\
\text { uptake(g/pot) }\end{array}$} & \multicolumn{2}{|c|}{ K content $(\%)$} & \multicolumn{2}{|c|}{ K uptake(g/pot) } \\
\hline & Seed & Straw & Seed & Straw & Seed & Straw & Seed & Straw & Seed & Straw & Seed & Straw \\
\hline \multicolumn{13}{|l|}{ Potassium humate } \\
\hline Control $\left(\mathrm{KH}_{0}\right)$ & 3.42 & 1.37 & 11.24 & 7.18 & 0.319 & 0.190 & 1.046 & 0.993 & 1.310 & 2.539 & 4.32 & 13.22 \\
\hline $5 \mathrm{mg} / \mathrm{kg}\left(\mathrm{KH}_{1}\right)$ & 3.73 & 1.73 & 17.14 & 11.53 & 0.360 & 0.212 & 1.651 & 1.410 & 1.620 & 2.779 & 7.48 & 18.40 \\
\hline $10 \mathrm{mg} / \mathrm{kg}\left(\mathrm{KH}_{2}\right)$ & 3.96 & 1.82 & 20.35 & 12.90 & 0.380 & 0.231 & 1.949 & 1.634 & 1.810 & 2.979 & 9.35 & 20.98 \\
\hline $\mathrm{SEm} \pm$ & 0.07 & 0.03 & 0.36 & 0.23 & 0.006 & 0.004 & 0.034 & 0.029 & 0.032 & 0.054 & 0.13 & 0.32 \\
\hline$\overline{C D}(\mathrm{p}=0.05)$ & 0.21 & 0.10 & 1.03 & 0.66 & 0.018 & 0.012 & 0.099 & 0.084 & 0.092 & 0.157 & 0.37 & 0.92 \\
\hline \multicolumn{13}{|l|}{ Bio-inoculants } \\
\hline Control $\left(\mathrm{B}_{0}\right)$ & 3.42 & 1.41 & 11.16 & 7.43 & 0.330 & 0.181 & 1.080 & 0.948 & 1.340 & 2.560 & 4.43 & 13.39 \\
\hline Rhizobium+VAM $\left(\mathrm{B}_{1}\right)$ & 3.74 & 1.68 & 16.86 & 10.88 & 0.339 & 0.200 & 1.531 & 1.288 & 1.620 & 2.790 & 7.39 & 17.94 \\
\hline Rhizobium+PSB $\left(\mathrm{B}_{2}\right)$ & 3.82 & 1.73 & 17.84 & 11.48 & 0.353 & 0.219 & 1.652 & 1.446 & 1.640 & 2.840 & 7.75 & 18.72 \\
\hline $\mathrm{VAM}+\mathrm{PSB}\left(\mathrm{B}_{3}\right)$ & 3.58 & 1.56 & 14.87 & 9.61 & 0.361 & 0.225 & 1.503 & 1.379 & 1.560 & 2.700 & 6.56 & 16.52 \\
\hline Rhizobium+VAM+PSB $\left(\mathrm{B}_{4}\right)$ & 3.96 & 1.84 & 20.49 & 13.29 & 0.381 & 0.232 & 1.976 & 1.668 & 1.740 & 2.940 & 9.12 & 21.10 \\
\hline $\mathrm{SEm} \pm$ & 0.09 & 0.04 & 0.46 & 0.30 & 0.008 & 0.005 & 0.044 & 0.037 & 0.041 & 0.070 & 0.16 & 0.41 \\
\hline $\mathrm{CD}(\mathrm{p}=0.05)$ & 0.27 & 0.12 & 1.33 & 0.85 & 0.024 & 0.016 & 0.128 & 0.108 & 0.119 & 0.202 & 0.47 & 1.19 \\
\hline
\end{tabular}


Table.2 Effect of potassium humate and bio-inoculants on yield and protein content of cowpea

\begin{tabular}{|c|c|c|c|}
\hline Treatments & Seed yield (g/pot) & Straw yield (g/pot) & Protein content $(\%)$ \\
\hline \multicolumn{4}{|l|}{ Potassium humate } \\
\hline Control $\left(\mathrm{KH}_{0}\right)$ & 3.26 & 5.18 & 21.38 \\
\hline $5 \mathrm{mg} / \mathrm{kg}\left(\mathrm{KH}_{1}\right)$ & 4.56 & 6.59 & 23.32 \\
\hline $10 \mathrm{mg} / \mathrm{kg}\left(\mathrm{KH}_{2}\right)$ & 5.10 & 7.01 & 24.75 \\
\hline $\mathrm{SEm} \pm$ & 0.09 & 0.13 & 0.45 \\
\hline $\mathrm{CD}(\mathrm{p}=0.05)$ & 0.26 & 0.37 & 1.31 \\
\hline \multicolumn{4}{|l|}{ Bio-inoculants } \\
\hline Control $\left(\mathrm{B}_{0}\right)$ & 3.23 & 5.19 & 21.38 \\
\hline Rhizobium + VAM ( $\left.\mathrm{B}_{1}\right)$ & 4.46 & 6.38 & 23.38 \\
\hline Rhizobium + PSB $\left(\mathrm{B}_{2}\right)$ & 4.62 & 6.54 & 23.88 \\
\hline $\mathrm{VAM}+\mathrm{PSB}\left(\mathrm{B}_{3}\right)$ & 4.11 & 6.07 & 22.38 \\
\hline Rhizobium + VAM + PSB $\left(\mathrm{B}_{4}\right)$ & 5.12 & 7.12 & 24.75 \\
\hline $\mathrm{SEm} \pm$ & 0.12 & 0.16 & 0.58 \\
\hline $\mathrm{CD}(\mathrm{p}=0.05)$ & 0.34 & 0.47 & 1.69 \\
\hline
\end{tabular}


The role of humic acid is to increase the plant growth and enhance the uptake of the nutrients from the soil, also act as a chelating agent and the fulvic acid helps to transfer of the nutrient contents through the plant (Prakash et al., 2013). Potassium humate increases the crop quality significantly and it increases stability of plant against alive and non-alive stresses (Gadimov et al., 2007). The increase in nutrient content, uptake and protein content with increasing potassium humate was also observed by El-Hefny (2010), Patil et al., (2010b), Patil et al., (2011b), Verma and Maurya (2013).

The visualization of data in Table- 1 also indicate that due to inoculation of cowpea seed with Rhizobium + VAM, Rhizobium + $\mathrm{PSB}, \mathrm{VAM}+\mathrm{PSB}$ and Rhizobium + VAM + $\mathrm{PSB}$, there was a significant increase in N,P and $\mathrm{K}$ content and uptake in seed and straw of cowpea in comparison to no inoculation. The increase in potassium content in seed and straw with Rhizobium + VAM + PSB was significantly higher over Rhizobium + VAM, Rhizobium + PSB as well as VAM + PSB inoculation. However, the N.P. and K content and uptake in seed and straw with inoculation of Rhizobium + VAM were also statistically at par with that of Rhizobium + PSB. This may be due to more nitrogen fixation by Rhizobium which in turn helped in better absorption and utilization of all the plant nutrients, thus resulting in more $\mathrm{N}$ and $\mathrm{P}$ content in seed and protein content. Similar, results have also been reported by Singh et al., (2006).The uptake of N.P. and K might have increased due to increased content and are in accordance with those of More et al., (2002) who observed higher N and P uptake due to inoculation of seed with PSB. VAM increased nutrient uptake (Chaturvedi et al., 1987) through reduction of the distance that nutrient must diffuse to plant roots by accelerating the rate of nutrient absorbing surface (Bowen et al., 1975).
The data presented in Table 2 indicate that with the application of potassium humate, there was a significant increase in seed yield and straw yield per (g/pot) of cowpea under $\mathrm{KH}_{1}$ and $\mathrm{KH}_{2}$ treatments as compared to control $\left(\mathrm{KH}_{0}\right)$. The results corroborate the finding of Selim et al., (2010), Patil et al., (2011), Magdi et al., (2011), Ananthi and Vanangamudi (2013), who also reported that use of potssium humate could increase yield.

It is evident from the data in Table 2 that due to inoculation of cowpea seed with Rhizobium + VAM, Rhizobium + PSB, VAM + PSB and Rhizobium + VAM + PSB, there was a significant increase in seed yield and straw yield $(\mathrm{g} / \mathrm{pot})$ of cowpea in comparison to control. The increase in seed yield and straw yield (g/pot) with Rhizobium + VAM + PSB was significantly higher over Rhizobium + VAM, Rhizobium + PSB as well as VAM + PSB inoculations. Inoculation of PSB also significantly enhanced the yield and yield attributes of cowpea. Tomar et al., (2001) in blackgram, Chalka (1999) and Balachandran et al., (2005) in greengram also reported similar results.VAM inoculation in soil significantly plays an important role in $\mathrm{P}$ cycling, mobilization and uptake by plants. The Earlier $\mathrm{P}$ availability, greater root extension, higher nutrient uptake, higher photosynthesis and balanced portioning are the main factors of significant increase in yield attributes and yield.

Since protein content of seed is essentially a manifestation of $\mathrm{N}$ content. Increased $\mathrm{N}$ content due to application of potassium humate@10mg/kg and seed inoculation with Rhizobium, PSB, VAM resulted in higher protein content because of their beneficial role in enhancing $\mathrm{N}$ content in seed. Findings of Chavan et al., (2008) and Senthil kumar and Sivagurunathan (2012) also provide support to the results of present investigation. 


\section{References}

Ananthi, K. and Mallika, V., 2013. Foliar Application of Humic Acid with Brassinosteroid on chlorophyll content and yield of Greengram (Vigna radiata (L.) Wilczek). Legume Res., 36: 241244.

Balachandran, S., Deotale, R.D., Hatmode, C.N., Titare, P.S. and Thorat, A.W. 2005. Effect of bio-fertilizers (Pressmud, Rhizobium and PSB) and nutrients (NPK) on morphophysiological parameters of greengram. J. Soils and Crops, 15: 442-447.

Bowen, G.D., Bevege, D.I. and Mosse, B. 1975. The phosphate physiology of vesicular arbuscular mycorrhizas. In: Endomycorrhizas, Eds. Sanders, F.E., Mosse, B. and Tinker, P.B. Academic Press, London: 241-260.

Chalka, M. 1999. Effect of P, S and PSB on cowpea. M.Sc. (Ag.) Thesis, Rajasthan Agricultural University, Bikaner.

More, K.A., Gaikwad, C.B., Dahat, D.V. 2002. Effect of N, P, Rhizobium and phosphate solublizing bacteria on groundnut. J. Maharashtra Agri. Univ., 27: 202-204.

Chaturvedi, C., Sharma, A.K. and Singh, R. 1987. Plant growth responses to Vesicular-Arbuscular Mycorrhiza (VAM) in chickpea (Cicer arietinum) In : Mycorrhiza Round Table, Proceedings of a Workshop (13-15 March), New Delhi : 402-409.

Chavan, P.G., Shinde, V.S., Kote, G.M., Solunke, P.S. and Bhondve, A.A. 2008. Response of sources and levels of phosphorus with and without PSB inoculation on growth, yield and quality of soybean. Res. Crops, 9: 286-289.

El-Hefny, E.M. 2010. Effect of saline irrigation water and humic acid application on growth and productivity of two cultivars of cowpea (Vigna unguiculata L. Walp). Australian J. Basic and Appl. Sci., 4: 6154-6168.

Gadimov, A., Ahmaedova, N., Alieva, R.C. 2007. Symbiosis nodules bacteria Rhizobium legominosarum with peas (Pisumsativum) nitrate reductase, salinification and potassium humate. Azerbaijan Nat. Acad.. Sci., Azerbaijan. 25-31.

GOI. 2013. Agricultural statistics at a glance. Directorate of Economics and Statistics. Department of Agriculture and Cooperation, Ministry of Agriculture. $\mathrm{http} / /$ dacnet.nic.in.

GOR. 2013. Vital Agricultural Statistics, 20012-13, Directorate of Agriculture, Government of Rajasthan, Jaipur. www. rajasthankirshi. org.in.

Jackson, M.L. 1973 Soil Chemical Analysis, Prentice Hall, Pvt. Ltd, New Delhi, pp.239-241.

Lowry, O.H., Rosebrough, N.J., Lewis, F.A. and Randall, R.J. 1951. Protein measurement with Folin Phenol reagent. J. Biol. Biochem., 193: 265-275.

Magdi, T., Abdelhamid, E.M. Selim and ELGhamry, A.M. 2011. Integrated effect of Bio and Mineral fertilizers and Humic Substance on growth, yield and nutrient contents of fertigated Cowpea (Vigna unguiculata L.) grown on Sandy soils. J. Agronomy, 10: 34-39.

More, K.A., Gaikwad, C.B., Dahat, D.V. 2002. Effect of N, P, Rhizobium and phosphate solublizing bacteria on groundnut. J. Maharashtra Agri. Univ., 27: 202-204.

Narula, N. and K.G. Gupta. 1986. Ammonia excretion by Azotobacter chroococcum in liquid culture and soil in the presence of manganese and clay minerals. Plant and Soil, 93: 205-209.

Patil R.B., More A.D., Kalyankarm., Andwadje, S.S. 2011. Effect of potassium humate on nutrients uptake 
of Glycine max, Phaseolus mungo and Triticum aestivum, Plant Sci. Feed, 1: 174-178.

Patil, R., Junne, S., Mokle, S. and Santuk, W. 2010. Effect of potassium humate on vegetative growth and protein contents of Glycine $\max (\mathrm{L}$.$) \quad Merrill and$ Phaseolus mungo (L.). Arch. Appl. Sci. Res., 2: 76-79.

Prakash, P., Samundeesari, R., Navaneethan, G., Palagani Padmaja, B., Ramakrishnan, Anurima Chatterjee and Mary Magar Nisha, 2013. Influence of potassium humate on morus alba and analysis their nutrient content. Int. J. Agronomy and Agri. Res., 3: 1-6.

Richards, L.A. (Ed.) 1954. Diagnosis and Improvement of Saline and Alkali Soils. USDA Agriculture Handbook, 60, Washington D.C.

Sahar, M., Zaghloul, E.M., Fatma, El-Quesni and Azza, A.M. 2009. Influence of Potassium Humate on Growthand Chemical constituents of Thuja Orientalis L seedlings. Ozean J. Appl. Sci., 2(1): 73-78.

Sarig, S., A. Blum and Y. Okon. 1988. Improvement of water status and yield of grown grain sorghum by inoculation with A. brasiliense. J. Agric. Sci., 110: 271-278.

Selim, E.M., El-Neklawy, A.S. and Mosa, A.A. 2010. Humic acid fertigation of drip irrigated cowpea under sandy soil conditions. American-Eurasian J. Agri. Environ. Sci., 8: 538-543.

Selvakumar, G., Reetha, S., Thamizhiniyan,
P. 2012. Response of biofertilizers on growth, yield attributes and associated protein profiling changes of black gram (Vigna mungo L. Hepper). World App. Sci. J., 16: 1368-1374.

Senthilkumar, P.K. and Sivagurunathan, P. 2012. Comparative effect on bacterial biofertilizers on growth and yield of green gram (Phaseolus radiata L.) and cow pea (Vigna siensis Edhl.). Int. J. Curr. Microbiol. Appl. Sci., 1: 34-39.

Serenella, N., Pizzeghelloa, D., Muscolob, A. and Vianello, A. 2002. Physiological effects of humic substances onhigher plants. Soil Biol. Biochem., 34: 15271536.

Singh, $\quad$ A.K., Tripathi, $\quad$ P.N., Kumar, R.P., Srivastava, A.K. andRoom Singh, 2006. Response of nitrogen, phosphorus levels and Rhizobium inoculation on nutrient uptake, yield and protein content of cowpea. J. Soils and Crops, 16: 475-477.

Snell, F.D. and Snell, C.T. 1949. Colorimetric Method Analysis; D. Van Nostrand: New York, pp. 804-805.

Tomar, A., Kumar, N., Pareek, R.P. and Chaube, A.K. 2001. Synergism among VAM, phosphate solubilizing bacteria and rhizobium for symbiosis with black gram (Vigna mungo L.) under field conditions. Pedosphere, 11: 327-332.

Verma, R. and Maurya B.R. 2013. Effect of Bio-Organics and fertilizers on yield and nutrient uptake by Cabbage. Annals of Plant and Soil Res., 15: 35-38.

\section{How to cite this article:}

Pradip Tripura, Sunil Kumar and Rajhans Verma. 2017. Effect of Potassium Humate and Bioinoculants on Nutrient Content, Uptake and Quality of Cowpea (Vigna unguiculata (L.) Walp). Int.J.Curr.Microbiol.App.Sci. 6(2): 1735-1741. doi: http://dx.doi.org/10.20546/ijcmas.2017.602.194 